
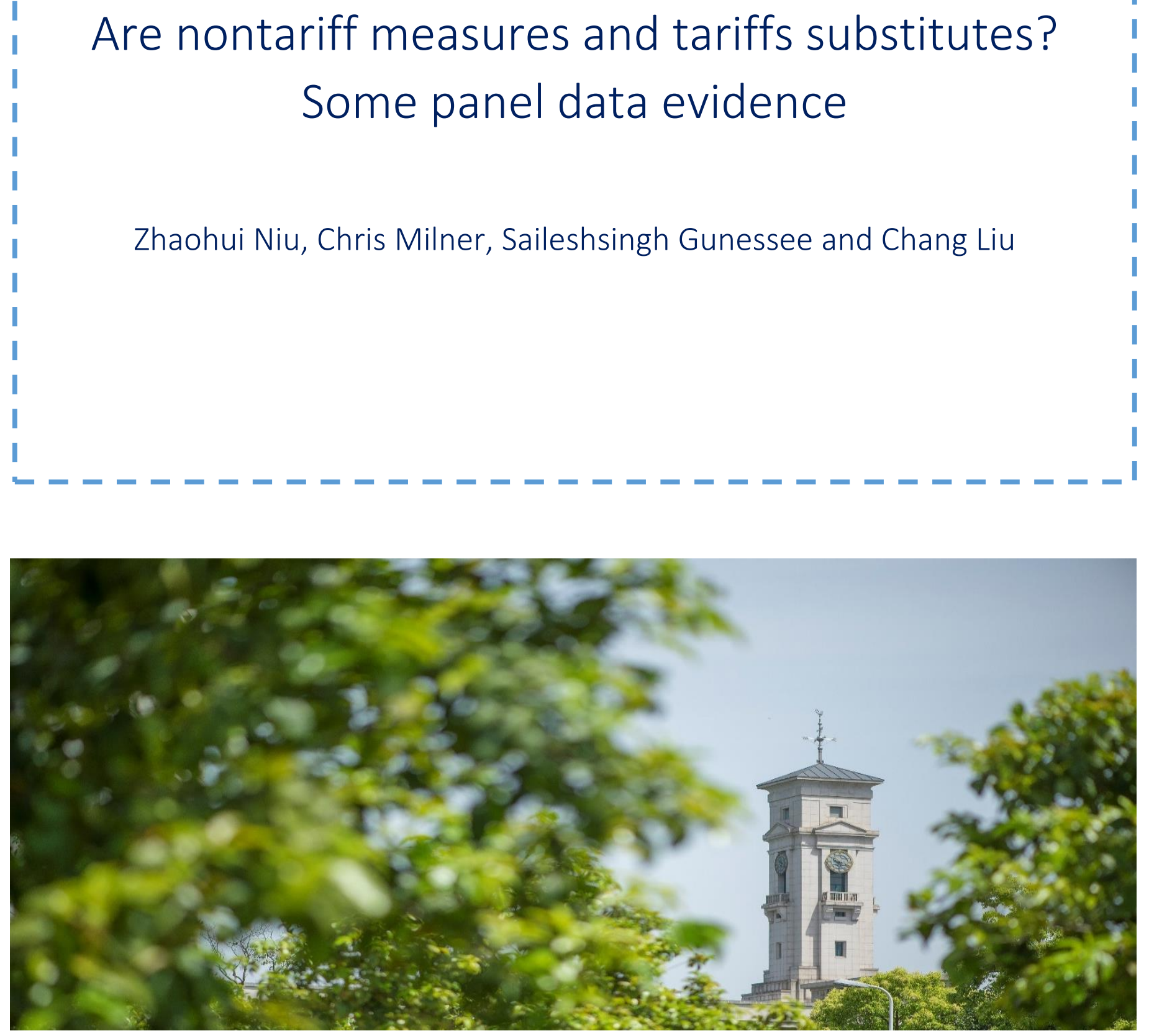
University of Nottingham Ningbo China, 199 Taikang East Road, Ningbo, 315100, Zhejiang, China.

First published 2020

This work is made available under the terms of the Creative Commons Attribution 4.0 International License:

http://creativecommons.org/licenses/by/4.0

The work is licenced to the University of Nottingham Ningbo China under the Global University Publication Licence:

https://www.nottingham.edu.cn/en/library/documents/researchsupport/global-university-publications-licence-2.0.pdf 


\title{
Are Non-Tariff Measures and Tariffs Substitutes? Some Panel Data Evidence
}

\author{
Zhaohui Niu ${ }^{\mathrm{a}}$, Chris Milner ${ }^{\mathrm{b}}$, Saileshsingh Gunessee ${ }^{\mathrm{c} *}$, Chang Liu ${ }^{\mathrm{d}}$ \\ a School of Public Administration, Beihang University, No. 37 Xueyuan Road, Beijing 100191, China \\ b School of Economics, University of Nottingham, NG7 2RD, UK \\ ${ }^{c}$ Nottingham University Business School China, University of Nottingham Ningbo China, 199 Taikang \\ East Road, Ningbo 315100, China \\ ${ }^{\mathrm{d}}$ School of Economics, University of Nottingham Ningbo China, 199 Taikang East Road, Ningbo \\ 315100, China
}

October, 2019

\begin{abstract}
Using new estimates of ad-valorem equivalent (AVE) of non-tariff measures (NTMs) over time, this paper examines NTMs and tariffs relationship for a sample of 70 economies for 4949 products at the 6-digit HS level over the period 2003-2015. A panel data methodology models the lagged adjustment of NTMs to tariffs, consistent with a causal relationship. Trade policy substitution is found when the models are estimated in both levels and changes; with this holding for both OECD and non-OECD countries, but not for the agriculture sector in OECD countries. Overall, there is fairly complete substitution between policy instruments in absolute terms.
\end{abstract}

Key words: Non-tariff measures, tariffs, substitutes, complements, trade policy

JEL: F13, F14

*Corresponding author: Phone: +86(0) 5748818 0000-8231

Email: saileshsingh.gunessee@ nottingham.edu.cn

\section{Introduction}

The decline in tariffs over the past two decades due to tariff liberalization associated with multilateral, bilateral and regional trade agreements, prompts the question as to what has happened to other trade policy instruments as a result of these tariff cuts (Baldwin, 2016; Bown, 2014; Hoekman and Nicita, 2011). The incidence and level of non-tariff measures (NTMs) are widely documented as having grown over the same period (Ghodsi et al., 2017; Nicita and Gourdon, 2013; Niu et al., 2018; WTO, 2012). It is natural to consider whether NTMs have risen in general and for reasons unrelated to tariff reforms, or whether NTMs have increased because of tariff cuts and with greater increases in the use of NTMs being on tariff lines where tariff rates have been cut most. Of course an overall picture of falling tariffs and increased use of NTMs may hide mix relations at the product or country level, with complementarity (declining tariffs and NTMs) in some cases and a preponderance of areas where instrument substitution prevails. 
There is not a clear consensus on this issue to be found in the existing empirical literature. Although a significant number of studies find trade policy substitution between tariffs and NTMs, this finding is sometimes weak and found mostly for developing countries. Further a number of studies identify a heterogeneous relationship determined by country or product characteristics (Beverelli et al., 2014; Bown and Tovar, 2011; Broda et al., 2008; Feinberg and Reynolds, 2007; Herghelegiu, 2018; Kee et al., 2009; Ketterer, 2016; Limão and Tovar, 2011; Moore and Zanardi, 2011; Orefice, 2017; Ronen, 2017; WTO, 2012). Indeed a few studies identify a significant complementary relationship between the two trade policy instruments (Dean et al., 2009; Goldberg and Pavcnik, 2005; Lee and Swagel, 1997; Trefler, 1993).

This paper contributes to this literature by examining the NTM-tariff relationship at a disaggregated 6-digit harmonized system (HS) level over the period 2003-2015 for a sample of 70 economies for 4949 products, using newly available data on non-tariff measures and detailed estimates of ad-valorem equivalent (AVE) of NTMs over time. Given the availability of estimates over time across economies and products, we adopt a panel data methodology to investigate the NTM-tariff relationship in levels and changes. Our empirical approach allows us to draw inferences about the causal link between current NTMs and lagged tariffs at the detailed product level. Further, the panel nature of the data allows us to control for productcountry and time specific fixed effects, and increase precision in the capturing of the NTMtariff relationship at the product level.

The present paper makes a number of contributions relative to the existing literature. Our approach uses ad-valorem equivalents (AVEs) of core NTMs and common metric therefore across alternative trade policy instruments, both non-tariff and tariff in nature. This is achieved by using estimates of AVEs of NTMs, computed using the methodology of Kee et al. (2009), at discrete points in time as a first step, that is, three-year intervals over the period 2003-2015 (Niu et al., 2018). We obtain the tariff equivalent of NTMs affecting each product in each importing economies at each point in time, and can thus directly compare the effects on import prices of changing NTMs and tariffs (Ronen, 2017). This NTM measure has the merit of being estimated econometrically and of dealing explicitly with potential endogeneity of NTMs with 
respect to imports (and the current or contemporaneous tariff), delivering a 'clean' non-tariff measure at the product level. It is this AVEs of NTMs that is then used to model the NTMlagged tariff relationship.

In contrast, most extant empirical studies employ proxy measures of NTMs that are not directly comparable to tariff rates. In effect, much of this literature focuses on the 'incidence' of NTMs to establish the NTM-tariff link, where they estimate how tariffs affect the probability of NTMs being deployed (see Beverelli et al., 2014; Feinberg and Reynolds, 2007; Herghelegiu, 2018; Ketterer, 2016; Limão and Tovar, 2011; Moore and Zanardi, 2011; Orefice, 2017), or the extent of NTMs through frequency and coverage ratios (see Broda et al., 2008; Lee and Swagel, 1997; WTO, 2012). The studies by Kee et al. (2009), Limão and Tovar (2011) and Ronen (2017) are rare examples that use tariff equivalents of NTMs. However, as outlined below, an important limitation facing these studies is the absence of information on NTMs over time and the associated constraint of having to model the NTM-tariff relationship in cross section only.

In the present study we are able to empirically model the usage of trade policy instruments over time. The NTM-tariff relationship is investigated in both 'levels' and 'changes'. The latter allow us to model how countries have adjusted NTM usage in response to changes in tariffs. Moreover, the data structure allows for the explicit modelling of the NTM-lagged tariff relationship. This has the technical advantage of reducing concerns over simultaneity (and endogeneity) issues associated with current or contemporaneous NTMs and tariffs. It also gives greater credibility to any causal interpretation of the impact of lagged tariffs on the AVE of NTMs, in particular in the context of political economy processes and administrative implementation of adjustments in NTMs that can be expected to take time. This is in contrast to existing studies that have confined their estimation to one point in time (see Kee et al., 2009; Lee and Swagel, 1997; Limão and Tovar, 2011; Ronen, 2017), or eschewed the kind of dynamic aspects of policy adjustment that a panel framework allows. ${ }^{1}$

\footnotetext{
${ }^{1}$ Several studies use tariff 'changes' as their main explanatory variable (see Herghelegiu, 2018; Moore and Zanardi, 2011; Orefice, 2017), with some solely focused on tariff 'reduction' (see Beverelli et al., 2014; Feinberg and Reynolds, 2007; Ketterer, 2016), while others use tariff 'levels' (see Kee et al., 2009; Ronen, 2017; WTO, 2012).
} 
A final contribution and merit of our study is that it is 'comprehensive' in nature. It is comprehensive in that our tariff equivalent NTMs incorporates the effects of all core NTMs, namely, price controls, quantity controls, monopolistic measures, and technical measures. It is comprehensive also in terms its disaggregated product (6-digit HS level) coverage. A disaggregated study of the NTM-tariff relationship has been argued to be preferable over broader industry analysis, as the latter is likely to mask the effect at individual product lines and thus provide an inaccurate estimated coefficient on the relationship (see Feinberg and Reynolds, 2007; Ketterer, 2016). Some previous studies have been narrowly focused on a single specific NTM instrument, such as antidumping, and/or conducted at an industry or sectoral level of disaggregation (see Beverelli et al., 2014; Feinberg and Reynolds, 2007; Lee and Swagel, 1997; Limão and Tovar, 2011; Moore and Zanardi, 2011; Orefice, 2017).

In the current analysis we measure the AVE of NTMs in multilateral trade i.e. as an average price effect of NTMs on imports from all sources. We do so in order to explore the overall relationship between tariff and non-tariff measures, not the relationship between these policy instruments with each trading partner separately. Clearly for some purposes one would want or need to measure the bilateral AVEs of NTMs. When concerned for example with competition in domestic markets by imports from alternative sources, estimates of the AVE of bilateral NTMs would be essential. Even where there is variation in a country's bilateral tariffs at the industry level due to tariff preferences arising from bilateral/regional trade agreements of preference schemes for developing countries, one should not necessarily expect substitutability or complementarity between trade policy instruments to apply in a bilateral setting. WTO rules or the threat of retaliation may constrain the use of source-specific NTMs. The obvious exception to this is in the case of contingent protection measures, such as AD duties. We do not, however, include contingent protection measures for the present purpose in our measure of the incidence of core NTMs, in part because such measures are typically targeted on a limited set of products and trade partners. Some studies (e.g. Egger and Nelson, 2011) have generated estimates of AVEs in bilateral trade in order to investigate the extent to which anti-dumping 
measures affect bilateral trade flows, but here the aim is to investigate the relationship in the use of trade policy instruments (tariffs and core NTMs) in multilateral trade.

The paper is structured as follows. Section 2 reviews the relevant theoretical and empirical literature. Section 3 reports on the method and data used to measure the tariff-equivalent of NTMs. Section 4 sets out the conceptual framework and empirical specification. The empirical findings are presented in Section 5, while Section 6 concludes.

\section{Literature}

Several studies have explored the relationship between tariffs and NTMs. In general, there is no consensus, with some theoretical work and empirical work concluding that tariff and NTMs are substitutes, while other studies find them to be complements.

Starting with the theoretical stream of the literature, according to the influential 'Law of Constant Protection', in order to reach their policy goals, governments operate target levels of overall protection towards import products (Bhagwati, 1988). Even with reduction in tariffs through successive multilateral and regional trade agreements, governments can turn to greater use of NTMs to keep overall protection at the targeted level. The prediction of the law is that tariffs and NTMs are substitutes.

Several attempts at theoretically grounding the NTM-tariff link have been made. Yu (2000) provides a political economy explanation of tariff reduction and the NTM-tariff trade-off. Trade policy substitution is found to be absent with foreign competition, unless vested interests from import-competing firms contribute to government welfare so as to outweigh informed consumers' preference for less trade protection. Anderson and Schmitt (2003) set up a model to analyze how trade liberalization affects trade policy. They find that when both tariffs and quotas are constrained due to trade agreements commitments, then antidumping policies (as non-tariff barrier), are likely to be employed; with quotas being the predominant trade policy measure, if only the use of tariffs is constrained. Addressing the question of policy choice between tariffs and NTMs, Limão and Tovar (2011) show that tariff reduction commitments increase the likely adoption of NTMs and their restrictiveness. Governments are willing to 
make such commitments even if it means shifting to less efficient NTBs, as it can raise their political bargaining value vis-à-vis special interest groups.

There are also a few studies suggesting a complementary relationship between tariffs and NTMs. Vousden (1990) suggests that, depending on the level of pre-existing tariff protection, the joint impact of a quota and a tariff on domestic prices could lead to complementarity. Another explanation for complementarity can be found in the 'special interest politics' model of Grossman and Helpman (1994) where the implementation of trade policies are influenced by the lobby behavior of interest groups, where increased lobbying for certain important sectors drives up both tariff and the NTM protection.

The study of Essaji (2010) provides an example of a theoretical piece that illustrates the possibility of both complementarity and substitutability. Setting up a model where the government's objective function depends on consumer surplus, domestic firm's profits, consumption externality and the tariff revenue, he studies how a tariff reduction could affect technical regulations imposed on foreign firms. He finds that if the government cares about the negative externality from consuming poor quality products, a tariff reduction could lead to higher technical regulations, as the NTM's marginal impact on the consumption externality is important. With the concern about the negative externality, then increased technical regulations will substitute for a tariff reduction. However, if the foreign firm has a significant domestic presence then a tariff reduction implies consumers face lower prices and improved consumer surplus. Though the technical regulation favors the domestic firm and shifts profits to it, because consumer surplus is so important, the government could raise welfare not by raising the NTM but easing it when cutting the tariff. In this case we have technical regulation and tariffs as complements.

Notwithstanding the above theoretical works, the question of the NTM-tariff relationship remains an empirical one. Using an endogenous trade protection lens Trefler (1993) investigates how trade policy instruments affect US import policy. He finds tariffs and NTMs affect imports in the same direction, suggestive that tariffs and NTMs are complement to each other. Lee and Swagel (1997) extend the endogenous protection explanation by using industry- 
level data on production, trade flows and trade barriers for 41 countries. By regressing NTBs on tariffs, they find a significant positive complementary link between tariffs and NTBs.

Goldberg and Pavcnik (2005) in their study of trade liberalization in Colombia find a positive NTM-tariff relationship, whereby NTMs were not replacements for tariffs. Dean et al. (2009) use city-level retail data to estimate the price effect of NTMs directly on 47 consumer products for more than 60 countries in the year 2001. Generally, a higher tariff for a product is associated with a higher probability of NTM implementation, depicting NTMs and tariffs as complements - though this result doesn't hold for all product categories.

A few studies explore the relationship between tariffs and a specific type of NTM, such as antidumping (AD) measures. Feinberg and Reynolds (2007) study the spread of AD after a comprehensive tariff reduction. They find that tariff reduction after the Uruguay Round increased the probability of a country implementing antidumping measures. In other words, the antidumping measures substitute for tariffs. Following in similar vein, with a focus on AD, Moore and Zanardi (2011) examine how cuts in applied tariff rates affected AD initiations for 35 countries over the period 1991 to 2002. They find that tariff reductions do not increase the probability of $\mathrm{AD}$ initiations in general. However, trade policy substitution is observed for a few developing economies who rely heavily on $\mathrm{AD}$. Notwithstanding this finding, the investigation by Bown and Tovar (2011) of trade reforms in India reveal that large tariff cuts did raise the usage of $\mathrm{AD}$ and safeguards as alternative policy instruments. Such trade policy substitution of specific NTMs for tariff cuts is also reported by Ketterer (2016) for the EU, again in the context of $\mathrm{AD}$ investigations.

Another stream of this empirical literature examines NTMs as specific trade concerns (STCs) for Technical Barriers to Trade (TBT) and Sanitary and Phytosanitary Measures (SPS). Beverelli et al. (2014) show that policy substitution between tariffs and SPS are observed for both developed and developing world, but in the TBT sample this holds only in developed countries. Orefice (2017) reports that as a consequence of tariff cuts, SPS and TBT measures are used to restrict trade. Herghelegiu (2018) documents substitutability between NTMs and 
tariffs, where products that experience tariff reductions increase the probability of being subjected to NTM protection.

This finding of 'substitutability' has been confirmed by Broda et al. (2008) in their broader examination of NTMs. They show the United States set higher NTMs following its GATT/WTO tariff commitments, given the limited ability to use tariffs. An empirical investigation of the NTM-tariff relationship reported in the 2012 World Trade Report (see WTO, 2012), highlights a negative link between coverage and frequency measures of NTMs with tariffs, for both SPS and TBT, across countries and HS2 sectors.

After their estimation of AVEs of NTMs, Kee et al. (2009) use three sets of simple regressions, to examine the relationship between their estimated AVEs of NTMs and tariffs. Though their estimation with either country fixed effects or product fixed effects included reveal a positive tariff-NTM relationship, when both country fixed effects and product fixed effects are controlled for, the correlation between tariffs and NTMs becomes negative, suggesting policy substitution.

Two studies ground their estimation of the NTM-tariff relationship on the Kee et al.'s methodology to estimate AVEs of NTMs, namely Limão and Tovar (2011) and Ronen (2017). The former exploits the variation in tariff constraints to examine the impact on NTMs for Turkey. They find evidence of substitution between the two trade policy instruments with tariff commitments - due to WTO and trade agreements with the EU - leading to higher AVEs of NTMs. However, their finding is of incomplete trade policy substitution as NTMs only partially offset for reduced tariff protection. Ronen (2017) reports NTMs substituting for tariffs mostly for developing economies, but complement each other in the case of the high-income economies. A key feature of all three studies is that the estimated NTM-tariff relationship is derived from a cross section estimation strategy.

In summary, extant studies have generally eschewed the use of a tariff equivalent of NTMs that is directly comparable to tariffs. Some of these studies have also tended to focus on specific NTM measures and used more aggregated industry-level data. Furthermore, although panel estimation is used in some studies, this is not the case for those studies closest to the present 
one, namely ones using AVEs of NTMs and common metric for measuring the trade barrier effect of the two trade policy instruments.

\section{Measuring Tariff-Equivalents of NTMs}

\section{Estimating AVEs of NTMS}

The estimation of the AVEs of NTMs follows Kee et al. (2009) to obtain tariff equivalents of NTMs at discrete points in time. The full details of the estimation procedure are reported in Niu et al. (2018). Here we report in summary on that procedure.

First, 'constrained' imports, with the effect of tariffs allowed for, are taken as the dependent variable: the NTM effect being modelled as an additional restriction on import quantity (see equation 1 below). ${ }^{2}$

$\ln m_{n c}-\varepsilon_{n c} \ln \left(1+t_{n c}\right)=\alpha_{n}+\left(-e^{\left(\beta_{n}^{\text {Core }}+\sum_{k} \beta_{n k}^{\text {Core }} C_{c}^{k}\right)}\right) \operatorname{Core}_{n c}+\sum_{k} \alpha_{n k} C_{C}^{k}+\kappa_{n c}$

where $m_{n c}$ represents the import volume of product $n$ by country $c$. It is normalized import volume, as the world price is taken as exogenous for all products at unit price. $\alpha_{n}$ as the product line intercept consists of product characteristics that do not vary across countries. The dummy variable Core $_{n c}$ depicts the presence of a core NTM for product $n$ in country $c$.

$t_{n c}$ is the ad-valorem (effectively applied) tariff on product $n$ in country $c$, and $\varepsilon_{n c}$ time invariant import demand elasticity for product $n$ in country $c . \beta_{n c}^{\text {Core }}$ captures the quantity effects of the presence of core NTMs, which vary across countries and products. $C_{c}^{k}$ controls for country characteristics, with $\alpha_{n k}$ being the coefficients for the country-specific characteristics.. The country-characteristics include GDP, capital/GDP, labor/GDP, , and land/GDP, along with a dummy for islands and the weighted distance to the global market as two gravity variables.

To take full advantage of the data variation, across products and countries, without running out of degrees of freedom, the estimation of Eq. (1) allows decomposition into country

\footnotetext{
${ }^{2}$ Although the NTM may be the binding constraint on the quantity of imports, we assume that the tariff barrier would remain with the removal of the NTM.
} 
specific factors and tariff line specific factors. This means that $\beta_{n c}^{\text {Core }}$, the coefficient on core NTM incidence, has both country $c$ and tariff line $n$ dimensions.

Eq. (1) expresses the coefficients for $\beta_{n c}^{\text {Core }}$ in exponential form, such that, the coefficients for core NTMs are constrained to be non-positive. ${ }^{3}$ This implies regressions estimated using nonlinear least square methods. The ad-valorem equivalents (AVEs) of NTMs were obtained using the estimated coefficients for $\beta_{n c}^{\text {Core }}$ :

$$
\operatorname{ave}_{n c}^{\text {Core }}=\frac{1}{\varepsilon_{n, c}} \frac{\partial \ln \mathrm{m}_{n c}}{\partial \text { Core }_{n c}}=\frac{e^{\beta_{n c}^{\text {Core }}-1}}{\varepsilon_{n c}}
$$

The AVEs of NTMs were estimated at the detailed product line for initially up to 97 countries at three-year intervals over the period 1997 to 2015, specifically for 1997, 2000, 2003, 2006, 2009, 2012 and 2015 and reported on in some detail in Niu et al. (2018). In the present work we concentrate on the post-2003 period, using a consistent classification of NTM incidence and consistently broad country coverage (70 countries, with all EU countries treated as a single identity). ${ }^{4}$

Given the potential endogeneity problem that the incidence of NTMs could be shaped by import quantity at the product level, exports, import volume change from the previous period, and the GDP-weighted average of the core NTMs for the five geographically neighboring countries are included as instrumental variables for the core NTM incidence dummy. The endogenous core NTMs dummy variable is modelled using the Heckman-Maddala treatment effect regression model, which runs a Probit regression model for each product line using the above instruments. The inverse Mills ratio estimated through this procedure is then added in estimating eq. (1).

Note that one could explore the relationship between bilateral tariffs and bilateral AVEs of NTMs, we seek here to investigate the relationship in a multilateral context. The incidence

\footnotetext{
${ }^{3}$ NTMs are assumed to exert a restrictive i.e. negative trade effect. The robustness of this assumption was checked on.

${ }^{4}$ The EU countries are treated as a single identity because EU countries negotiate as a whole in multilateral trade agreements and individual EU countries cannot set their trade policy. We take the simple average of AVEs of NTMs at the product level for all EU countries; with new members during the period treated as EU members throughout the period. For our sample of countries most of the new members joined the EU in 2004 (only one year after the start of our sample period), and as accession countries would have been converging their trade policies with the EU prior to membership.
} 
of many NTMs, especially the core NTMs concentrated on in the study, does not necessarily vary bilaterally. WTO rules constrain the ability of countries to set source-specific NTMs. Of course, non-discriminatory NTMs may induce bilateral AVEs that vary across source countries; due for instance to varying supply conditions in export countries or variations in product quality that induce variation import demand elasticity by source country. Indeed, this variation in bilateral AVEs is possible in the presence of both of NTMs and tariffs that are nondiscriminatory between different trade partners. ${ }^{5}$ We are concerned in the present analysis with investigating if and how variation across countries and time in the average (industry) tariffs applied multilaterally arising from changes in both MFN and preferential tariff rates affects the overall use of core NTMs. If, for example, a tariff change is induced by preferential tariff cuts on imports from specific sources, we do not necessarily anticipate a policy response relating only to NTMs on imports from sources subject to the preferential tariff cuts (WTO rules, the bilateral trade agreement itself or the threat of retaliation constraining the use of source-specific NTMs). Faced with increased imports from multiple or specific sources following a change in tariffs, we anticipate political economy pressures on trade policy makers to affect the multilateral incidence of NTMs.

\section{Data}

The data for the incidence of NTMs used to estimate the AVEs comes from UNCTAD's TRAINS (Trade Analysis Information System) database but which uses the new Multi-Agency Support Team (MAST) system to classify NTMs, as opposed to the old Trade Control Measures (TCMCS). The ability to track NTMs systematically over time and use a panel estimation to explore the tariff-NTM relationship is a distinctive feature of this new database. The AVEs of core NTMs (price controls, quantity controls, monopolistic measures and technical measures) are estimated for 70 economies, for altogether 4949 products at 6-digit HS level over the period 2003 to 2015 at three-year intervals (2003, 2006, 2009, 2012 and 2015). The effectively applied

\footnotetext{
${ }^{5}$ By adopting a multilateral approach we reduce the data challenge of having to measure import elasticities bilaterally, i.e. for each import source.
} 
tariff rate is used to measure tariffs using the data obtained from the UNCTAD'S TRAINS database at HS 6-digit product level. ${ }^{6}$ Further information on AVEs is given in Niu et al. (2018) and the detailed product level estimated AVEs at the product level for all countries and products is available at: www.nottingham.ac.uk/gep/links/index (with full data available upon reasonable request).

\section{Conceptual Framework and Empirical Methodology}

\section{NTM-tariff relationship}

We identify in the literature review that a number of different, political economy models of trade policy can derive alternative relationships between tariffs and the use of NTMs. We do not, however, seek here to test a specific model or to test between alternative models. Rather, we seek to explore the empirically revealed relationship between tariffs and NTMs without priors on whether there is no relationship, a substitution only, complementarity only or mixture of substitution and complementarity in different countries and sectors.

The intuition behind this absence of strong priors on the relationship can be illustrated by the theoretical work of Beverelli et al. (2014). They take product standards as the available NTM, and in their base model assume that NTMs such as product standards are unambiguously (marginal) cost increasing. ${ }^{7}$ Whether domestic producers prefer standards to be tightened (and marginal production costs increased) or relaxed in the face of a tariff reduction (resulting for example from binding regional or multilateral tariff agreements) depends on how this affects domestic firms' cost competitiveness relative to foreign suppliers. Domestic firms will lobby for a tightening of standards (i.e., for policy substitution of the higher NTM for the reduced tariff to take place), when domestic firms have a cost advantage over foreign producers in meeting the higher standard. By contrast, the possibility of policy complementarity also exists. In the face of the binding tariff reduction, domestic firms have an incentive to lobby for reduced

\footnotetext{
${ }^{6}$ This is in effect a weighted average of the tariff rates applied to a country's imports from different sources, and therefore captures the effects of both multilateral and preferential tariff liberalization.

${ }^{7}$ This assumption can be relaxed to allow for both costs and benefits from standards. In which case, it is the relative cost-benefit or net cost (rather than cost effects) of standards for domestic and foreign producers that determines the incentive for domestic producers to press for increases or reductions in standards.
} 
product standards where they have a cost disadvantage relative to foreign producers in meeting standards.

In this specific framework one might anticipate the relative incentive for domestic producers to lobby for policy substitution as opposed to policy complementarity to vary across sectors, with policy substitution (complementarity) the more likely outcome in sectors where standards are more (less) important and where domestic producers are cost competitive (uncompetitive). Similarly, in this specific framework one might expect greater evidence of policy substitution in advanced economies (with greater cost-competitiveness) than in less advanced economies.

But, it is not this specific model that we seek to test here. We seek only to give intuition to the potential ambiguity of the NTM-tariff relationship. In reality, the constraints on the use of policy instruments vary across countries and sectors for legal and institutional reasons, and depend on the reciprocity threat from trading partners. Furthermore, our empirical analysis is concerned with the NTM-tariff relationship in broad terms and not the relationship between tariff and a specific NTM, such as product standards. It may well be the case that producers in advanced economies have a greater incentive to lobby for the use of product standards than their counterparts in developing countries for the reasons indicated above, but producers in developing countries may well lobby in the face of tariff reductions for other forms of NTM such as quantity and price controls on imports. As we can see from Figure 1, over the period of our study there was an increase after 2006 in the overall frequency of use of quantitative restrictions as well as technical measures (alongside a fall in the average tariff from around 10\% in 2003 to about $6 \%$ in 2015).

*** FIGURE 1 ABOUT HERE ***

\section{Empirical specification}

The empirical model used to investigate the relationship between tariffs and NTMs at the product line level over time is:

$$
N T M_{n c t}=\alpha+\beta_{1} \text { Tariff }_{n c t-1}+\delta_{n c}+\tau_{t}+\epsilon_{n c t},
$$


where $N T M_{n c t}$ represents the estimated AVEs of NTMs for product $n$ in country $c$ at time $t . \alpha$ is the constant intercept term in the above regression. Tarif $f_{n c t-1}$ is the tariff rate for product $n$ in country $c$ at time $t-1$, with the sign of $\beta_{1}$ indicating the nature of the relationship between NTMs and tariffs. $\beta_{1}>0$ indicates that higher (lagged) tariff and NTM protection coexist for products across countries and time, or in other words, these policy instruments are complements. By contrast, $\beta_{1}<0$ is consistent with NTMs substituting for tariffs, while $\beta_{1}=$ 0 that there is no relationship between tariffs and NTMs. $\delta_{n c}$ is a dummy for product $n$ and country $c$ which controls for the product-country specific effects.

The product-country specific (fixed) effects control for products and countries that are more likely to be affected by higher levels of tariffs and AVEs of NTMs for historical and political economy reasons. $\tau_{t}$ represents the time-specific effects included to capture time variant factors and shocks affecting all economies, such as the 2008 financial crisis, that affected world trade and trade policies over time. $\epsilon_{n c t}$ is the error term. Both NTMs and tariffs are estimated after applying natural logarithms, strictly as $\ln (1+N T M)$ in order to avoid the dropping of zero observations where tariffs are zero (for the model in levels) or not subject to change between periods (for the model in changes).

Given that we have information on tariffs and AVEs over time, we can also investigate the response of NTM implementation to tariff change. In addition to the above model that explores the tariff - NTM relationship in 'levels', we explore how tariff changes affect NTMs. The estimation of the model in terms of 'changes' over time may be viewed as capturing the decision-making procedure of trade policy makers and providing stronger evidence of a causal relationship, with the substitutability or complementarity between tariffs and NTMs being a reflection of governments' ability and tendency to adjust policies when market conditions change. ${ }^{8}$ The 'dynamic' version of the model becomes:

$$
\Delta N T M_{n c t}=\alpha+\beta_{1} \Delta \text { Tariff } f_{n c t-1}+\delta_{n c}+\tau_{t}+\epsilon_{n c t}
$$

\footnotetext{
${ }^{8}$ The 'levels' and 'changes' models ae viewed as alternative possible models, and eq. 2 should not be viewed therefore as being derived by the first differencing of eq. 1 (which would difference out the constant/fixed effects terms).
} 
where $N T M_{n c t}$, Tariff $_{n c t}, \delta_{n c}, \tau_{t}$ are as previously defined. Note that we use lagged tariffs (levels or changes) as the right-hand side variable in both versions of the model. This is in order to capture the delays in the trade policy decision-making and implementation process, with changes in tariffs inducing lobbying by domestic interest groups, possible threats of retaliation by trade partners, administrative review, bureaucratic approval and possibly implementation of new or additional NTMs; the 'delayed' as opposed to contemporaneous relationship between tariffs and NTMs provide a more appropriate basis for inferring a causal effect of the change in policy instrument and an alternative policy instrument. Further, note that time $t$ in our analysis represents discrete points in time with three-year intervals over the period 2003-2015; 2003, 2006, 2009, 2012 and 2015 to be precise. This allowed for the smoothing of year-specific shocks in the measurement of the AVEs of NTMs, and captures the slow changing nature of trade policy (see Amiti and Khandewal, 2013).

As explained in section 3, the estimates of AVEs of NTMs we use in the modelling of the NTM-tariff relationship have the merit of being econometrically estimated as a first step, such that any endogeneity of NTMs with respect to imports and importantly tariffs is directly confronted. The estimation of the AVEs of NTMs follows Kee et al. (2009) to obtain the tariff equivalent of NTMs at discrete points in time. First, the 'constrained' level of imports, with the effect of tariffs allowed for, is taken as the dependent variable. Then the incidence of NTMs (the key explanatory variable) is further instrumented and several controls included in each estimated import demand function. This first-step estimation is carried out over a three-year span, averaging trade flows and other continuous variables to smooth out year-specific shocks.

As part of the robustness analysis, we seek further re-assurance that the possibility of reverse causation means that tariffs (even lagged) are not truly exogenous in our base regression results by reporting difference and system GMM estimates for (3) above. We also exploit variation in policy commitments enshrined in the WTO negotiations affecting specific sectors. In particular, as documented by Schott (1994), different forms of tariff reduction were applied from the agreements of the Uruguay Round. The Uruguay Round (UR) followed an ad hoc approach to cut tariffs on a sector-by-sector basis and countries had to cut tariff rates on average 
by about one-third of their pre-UR level. For some sectors, however, tariff cuts were mandated through a request-and-offer approach, the so-called "zero-for-zero". "Zero-for-zero" negotiations took place for some specified product sectors in which the main developed countries first reduced their tariffs to zero, followed by developing countries making substantial reduction for the same products (Schott, 1994).

Therefore, products with higher than average tariff reduction (for peak tariffs) and with "zero-for-zero" measures are defined as highly affected sectors, while the remaining products are defined as less affected sectors. We adopt this splitting of the sample by product to reestimate the models ( 3 and 4 ) to explore whether there is a stronger relationship between tariffs and NTMs for the product set where larger tariff cuts were imposed on individual countries by the multilateral negotiations. These higher cut sectors might be viewed as ones where countries were more constrained and where (for the current purpose) the cuts were more exogenous to national level trade policy setting.

\section{Empirical results}

\section{Base results}

Figure 2 shows the evolution over time of the overall average tariff and average AVE of NTMs for the full sample; revealing tariff levels to have been subject to constant slow decline, with NTMs fluctuating but generally higher at the period end than at the start. This is suggestive of substitution by NTMs for the decline in tariffs, with non-tariff protection becoming the increasingly dominant source of protection overall.

\section{*** FIGURE 2 ABOUT HERE ***}

Table 1 reports the summary statistics on average tariffs and AVEs, grouping economies as OECD and non-OECD (with the country abbreviations elaborated on in Appendix Table A.1). The average AVE of NTMs and applied tariff rate again confirms that NTM protection level was much higher than tariffs and growing in importance over the time period for both OECD and non-OECD countries. Average tariff rates decreased consistently over the sample period for non-OECD countries. Tariff rates in OECD countries declined a little initially and stayed constant thereafter. For our sample period bound and applied tariff rates in industrial 
had already been substantially reduced such that that there was limited scope for further reduction. Both the average tariff rate and AVE level (and therefore level of overall protection) were also much higher in general in non-OECD than OECD economies. This is in contrast to the argument of Hoekman and Nicita (2011) that NTMs increase with income per capita, mirroring the declining importance of tariffs; an argument that would lead one to expect a greater likelihood of substitution between these trade policy instruments for developed than developing countries.

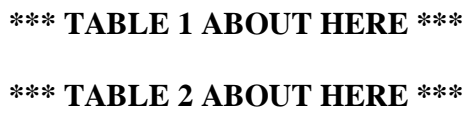

Table 2 reports the base estimates of eq. (1), with AVEs regressed on lagged levels (columns 1,2 and 3) and changes in tariffs (columns 4, 5 and 6); in each case initially without fixed effects, then with only product-country fixed effects and finally with both product-country and time fixed effects included in the specification. In levels, the pooled OLS regression with no fixed effects controlled for (col.1) generates a positively signed and statistically significant coefficient on the tariff variable, suggesting complementarity between tariff and non-tariff trade policy instruments. However, the sign on lagged tariff levels becomes significantly negative for the panel estimation with product-country fixed effects (col.2), though the magnitude of the negative coefficient is reduced markedly by the inclusion also of time fixed effects (col.3). For the alternative specification using lagged changes in tariffs as the explanatory variable, a negative and significant coefficient is obtained with or without fixed effects and for the alternative configurations of the fixed effects. Overall, our estimated base panel models provide evidence consistent with a substitutional relationship between tariffs and NTMs for the full sample of countries over this time period, with falling tariffs (typically) being followed by rises in NTM levels. ${ }^{9}$

Heterogeneity in the Tariff-NTM Relationship

\footnotetext{
${ }^{9}$ A similar conclusion is drawn if separate product and country effects are used rather than product-country fixed effects.
} 
Given the greater use of tariffs and greater overhang of bound over applied tariffs in developing countries and given the possibility of greater administrative capacity in developed countries to implement NTMs, one might be concerned that the results in Table 1 for the full sample hide important differences in the NTM-tariff relationship between developed and developing countries. ${ }^{10}$ In Table 3 we explore heterogeneity in the NTM-tariff relationship between country groupings, specifically between sub-samples of OECD and non-OECD countries and using the preferred panel specification which includes both product-country and time fixed effects.

\section{*** TABLE 3 ABOUT HERE ***}

The finding of policy substitution from the full sample holds in general for both OECD and non-OECD countries. A negative coefficient is found on the lagged tariff variable in both the levels and changes specification for both OECD and non-OECD countries, and with significance in all but column 4 (the changes specification applied to non-OECD countries). The fact that an absolutely larger coefficient is obtained in both the levels and changes models for OECD countries and that an insignificant coefficient is obtained for non-OECD countries in the case of the 'dynamic' model indicates that there is stronger support for the substitution relationship between NTMs and tariffs for OECD countries than for non-OECD countries.

Taken together these findings reveal some divergence from extant studies, which predominantly find NTM-tariff policy substitution to be a developing country phenomenon (see Moore and Zanardi, 2011; Ronen, 2017). It should be noted, however, that previous work tends to be concerned with the trade-off between tariffs and a specific type of NTM or to be reliant on cross-country evidence only. Here our finding is based on a comprehensive measure of NTMs and on estimates from a panel of cross country and over time information.

\section{*** TABLE 4 ABOUT HERE ***}

In Table 4 we investigate further whether and how the tariff-NTM relationship varies across sectors in OECD and non-OECD countries. It is clear from Table 4 that the overall

\footnotetext{
${ }^{10}$ The requirements for tariff reduction in multilateral negotiations have been different for developed and developing countries, including in the Uruguay Round, (Schott, 1994). Although Moore and Zanardi (2011) found that tariff reductions resulted in higher anti-dumping NTM incidence for developing economies, there are range of NTMs such are product standards that are more likely to be applied by developed countries.
} 
substitution result drawn from the previous results is in fact driven mainly by the manufacturing sector and more strongly in OECD than non-OECD countries. We obtain significantly negative coefficients in the case of the 'levels' model for the manufacturing sector in both OECD and non-OECD countries, albeit with a stronger substitutional relationship for OECD manufacturing than non-OECD manufacturing. By contrast, the estimated 'levels' model generates an insignificant relationship for OECD agriculture and a significantly positive relationship between NTMs and lagged tariffs for non-OECD agriculture. The negative overall relationship for non-OECD countries indicated by Table 3 is in fact masking a mixed relationship of complementarity for non-OECD agriculture and substitution for non-OECD manufacturing. Although this finding does not also hold for the 'changes' model, for which we find no significant relationship between tariffs and NTMs for either sector in the case of the non-OECD countries. By contrast, we find significant negative signs on lagged tariff changes for both OECD agriculture and manufacture sectors.

Table 5 shows heterogeneity in the NTM-tariff relationship through an additional samplesplitting across different sectors, as identified on the basis of commitments under the Uruguay Round (agreed in 1994 and implemented over 6 (10) years post-agreement by developed (developing) countries). As highlighted in section 4, 'zero-for-zero' negotiations took place for some specified product sectors, with developed countries reducing their tariffs to zero first, followed by developing economies committing to a reduction for the same products (Schott, 1994). We split the sample into two groups: products with above average tariff cuts and products with below average tariff cuts. The first type includes products with above average tariff cuts as well as products with zero-for-zero commitments, while the second type includes the rest of the products. ${ }^{11}$ Products with above average tariff reduction cover $67 \%$ of the sample while products with below average tariff reduction cover about $33 \%$. Given the differences in commitments and implementation speed between developed and developing countries, we

\footnotetext{
${ }^{11}$ Product groups with above-average tariff cuts are: metals; mineral products, precious stones and metals; electric machinery; wood, pulp, paper, and furniture; nonelectric machinery; chemicals and photographic supplies; and "other" manufactured articles. Products with zero-for-zero commitments are: pharmaceuticals, construction equipment, steel, distilled spirits, certain furniture, medical equipment, farm machinery, beer, toys and paper.
} 
retain the OECD/non-OECD sub-samples for the implementation of this split product/sector. Indeed one might anticipate evidence of a stronger substitutional relationship between NTMs and tariffs for sectors subject to larger tariff cuts, and possibly some difference between country types. $^{12}$

\section{*** TABLE 5 ABOUT HERE ***}

The results in Table 5 continue to provide evidence in support of a substitutional relationship between tariffs and NTMs, with negative signs (with one exception of an insignificant positive sign) on the lagged tariff variable in levels or changes specification and for above and below average UR tariff cuts for both OECD and non-OECD countries. There is, however, interesting variation in significance levels and the magnitude of the estimated coefficient in different sub-samples. In the levels specification there is an absolutely larger, and consistently significant, negative coefficient in the case of above average tariff-cutting sectors for both OECD and non-OECD countries. By contrast, there is a smaller (albeit still significant) substitutional effect found for below average tariff cutting sectors in the case of the OECD countries and no significant relationship in the case of the non-OECD countries for the low cut sectors; evidence therefore consistent with a stronger and more comprehensive substitutional relationship for OECD than non-OECD countries.

The conclusion above does not hold in the case of the 'changes' model. All the estimated coefficients on the tariff variable are negative, but only significant in the case of below average cut sectors in the case of non-OECD countries. By taking changes the sample period is truncated, however, and importantly the change in the dependent variable starts with the change over the period 2006-2009 which is after the scheduled full implementation of the UR tariff cuts (2000 for OECD countries and 2004 for non-OECD countries). This constrains the usefulness of the changes model to comment on the heterogeneity which we wish to explore. The levels model is more informative for the purpose at hand, and offers results in line with expectations.

\footnotetext{
${ }^{12}$ This is for the same reasons as indicated above for differences in the overall relationship for OECD and nonOECD countries and/or because the speed and degree of implementation of the tariff cuts differed between these country groups.
} 


\section{Further robustness analysis}

In order to check whether any reverse causation from lagged tariffs to the contemporaneous AVE level of NTMs means that we strictly cannot treat our tariff variable in our base results as exogenous, we report on difference GMM and system GMM estimations of the static model (eq. 3). ${ }^{13}$ Both estimators are designed for a small number of time periods and large number of units (here countries), where independent variables are correlated with past and possibly present realizations of the error term. System GMM imposes additional constraints, implying in the current context that trade policy in the sampled countries is not too far from steady state conditions over the sampled period. However, the system GMM estimator may have lower bias and higher efficiency than the first difference GMM estimator for the relatively small number of countries in the present sample.

\section{*** TABLE 6 ABOUT HERE ***}

We report both the difference and system GMM estimations of (3) for the full sample in Table 6 . The coefficient on lagged tariffs by both estimation methods is quite similar; negative and significant at the $1 \%$ level. This finding is consistent with the trade policy substitution result obtained in the base, panel regressions. Indeed, the GMM estimations suggest a stronger substitution effect, with an absolutely larger negative coefficient on the tariff variable. To confirm our findings from the base modelling for the various sub-samples reported on above, we also report in appendix table A-2 the system GMM estimates where the sample is split by economy type (OECD and non-OECD), product (subject to above and below average tariff cuts in Uruguay Round), and by sector (manufacturing and agriculture). We find support for the trade policy substitution hypothesis for these sub-samples.

\section{Conclusions}

With the proliferation of multilateral and bilateral trade agreements in recent years, tariffs have fallen to a relatively low level and NTMs are increasingly used as the main instrument of trade policy. In this paper, the aim is to formally investigate whether NTMs overall are substituting

\footnotetext{
${ }^{13}$ The difference GMM version of (3) is equivalent to the dynamic version of the model (4) with a lagged dependent variable added.
} 
for tariffs, using directly comparable tariff equivalent NTMs at the product-level for 80 countries over the period of 2003 to 2015 . We employ a panel methodology to investigate this relationship across countries and time, allowing for the lagged adjustment of NTMs to tariffs (modelled in levels and changes). This empirical strategy offers a credible basis for offering a causal interpretation to the estimated relationship between the AVEs of NTMs and tariff rates at the detailed product level, using AVEs of NTMs estimated in consistent and rigorous manner.

In summary, our findings are strongly consistent with trade policy substitution being present overall between NTMs and tariffs for the sampled countries and sample period, with effect tending to be stronger for the manufacturing sector, for OECD than non-OECD countries and for those sectors/products subject to higher than average multilateral tariff cuts. This finding is also confirmed by the GMM estimates. Although, in the case of non-OECD countries, we find some evidence of a mixed relationship in the case of the 'levels' model, with tariff and NTMs being complements in the case of non-OECD agriculture and substitutes in the case of non-OECD manufacturing.

With both our variables in natural logarithms we can interpret the coefficients on the tariff variable in our estimated models as elasticities. The average elasticity for the observed substitution relationship is apparently low overall, and not absolutely greater than -0.28 for specific sub-samples. One might conclude therefore that the NTM-tariff relationship is one subject to imperfect and incomplete trade policy substitution. It needs to be recognized, however, that tariff levels are on average much lower than the tariff-equivalent of NTMs, as demonstrated in Fig. 1 and in Table 1. With average tariffs typically of $10 \%$ or less in this period, a $10 \%$ decline in tariffs involves an absolute decline in tariffs of $1 \%$ point or less. With an average AVE of NTMs typically in excess of $40 \%$, an elasticity of -0.25 implies a $1 \%$ percentage point increase in the AVE for each $10 \%$ decrease in tariffs. In absolute terms, therefore, the trade policy substitution is much more complete!

\section{References}

Amiti, M. and A.K. Khandelwal (2013). Import competition and quality upgrading. Review of Economics and Statistics, vol. 95(2), pp. 476-490. 
Anderson, S. P. and N. Schmitt (2003). Nontariff barriers and trade liberalization, Economic Inquiry, vol. 41(1), pp. 80-97.

Baldwin, R. (2016). The Great Convergence: Information Technology and the New Globalization. The Belknap Press of Harvard University Press, Cambridge, Massachusetts.

Bhagwati, J.N. (1988). Protectionism. MIT Press, Cambrdige, Massachusetts.

Beverelli, C., Boffa, M., and Keck, A. (2014). Trade policy substitution: theory and evidence from specific trade concerns. WTO Staff Working Papers ERSD-2014-18.

Bown, C. P. (2014). Trade policy instruments over time. World Bank Policy Research Working Paper No. 6757.

Bown, C. P. and P. Tovar (2011). Trade liberalization, antidumping, and safeguards: evidence from India's tariff reform. Journal of Development Economics, vol. 96(1) pp. 115-25.

Broda, C., N. Limão, and D.E. Weinstein (2008). Optimal tariffs and market power: the evidence. American Economic Review, 98(5), pp. 2032-2065.

Dean, J. M., J. E. Signoret, R. M. Feinberg, R. D. Ludema and M. J. Ferrantino (2009). Estimating the price effects of non-tariff barriers. BE Journal of Economic Analysis \& Policy, vol. 9(1), pp. 1935-1682.

Egger, P. and D. Nelson (2011). How bad is antidumping: evidence from panel data? Review of Economics and Statistics, vol. 93(4), pp. 1374-90.

Essaji, A. (2010). Trade liberalization, standards and protection, BE Journal of Economic Analysis \& Policy, vol. 10(1), pp. 1-21.

Feinberg, R.M. and K.M. Reynolds (2007). Tariff liberalisation and increased administrative protection: is there a quid pro quo? The World Economy, vol. 30(6), pp. 948-961.

Ghodsi, M., J. Grübler, O. Reiter and R. Stehrer (2017). The Evolution of Non-Tariff Measures and their Diverse Effects on Trade. The Vienna Institute for International Economic Studies Research Report 419.

Goldberg, P. K., and N. Pavcnik (2005). Trade, wages, and the political economy of trade protection: evidence from the Colombian trade reforms. Journal of International Economics, vol. 66, pp. 75-105.

Grossman, G.M. and E. Helpman (1994). Protection for sale. American Economic Review, vol. 84 , pp. 833-850.

Herghelegiu, C. (2018). The political economy of non-tariff measures. The World Economy, vol. 41(1), pp. 262-286.

Hoekman, B. and A. Nicita (2011). Trade policy, trade costs, and developing country trade. World Development, vol. (39), pp. 2069-2079.

Kee, H.L., A. Nicita and M. Olarreaga (2009). Estimating trade restrictiveness indices, Economic Journal, vol. 119(534), pp. 172-199.

Ketterer, T.D. (2016). EU anti-dumping and tariff cuts: trade policy substitution? The World Economy, vol. 39(5), pp. 576-596.

Lee, J-W. and P. Swagel (1997). Trade barriers and trade flows across countries and industries. Review of Economics and Statistics, vol. 79(3), pp. 372-382.

Limão, N. and P. Tovar (2011). Policy choice: theory and evidence from commitment via international trade agreements. Journal of International Economics, vol. 85(2), pp. 186-205.

Moore, M. and M. Zanardi (2011). Trade liberalization and antidumping: is there a substitution effect? Review of Development Economics, vol. 15(4), pp. 601-19.

Nicita, A. and J. Gourdon (2013). A preliminary analysis on newly collected data on non-tariff measures. Policy Issues in International Trade and Commodities Study Series No. 53, UNCTAD, New York.

Niu, Z., C. Liu, S. Gunessee and C. Milner (2018). Non-tariff and overall protection: evidence from across countries and over time. Review of World Economics. vol. 154(4), pp. 675703.

Orefice, G. (2017). Non-tariff measures, specific trade concerns and tariff reduction. The World Economy, vol. 40(9), pp. 1807-1835. 
Ronen, E. (2017). Tariffs and non-tariff barriers: substitutes or complements. a cross-country analysis. Bank \& Credit, vol. 48(1), pp. 45-72.

Schott, J.J. (1994). Uruguay Round: An Assessment. Institute for International Economics, Washington DC.

Trefler, D. (1993). Trade liberalization and the theory of endogenous protection: an econometric study of US import policy. Journal of Political Economy, vol. 101(1), pp. $138-160$.

Vousden, N. (1990). The Economics of Trade Protection. Cambridge, New York: Cambridge University Press.

WTO (2012). Trade and public policies: A closer look at non-tariff measures in the 21 st century. World Trade Organization, Geneva.

Yu, Z. (2000). A model of substitution of non-tariff barriers for tariffs. Canadian Journal of Economics, vol. 33(4), pp. 1069-1090.

Table 1: Average AVE and Applied Tariff in OECD and non-OECD Countries (coefficient form: 2003-2015)

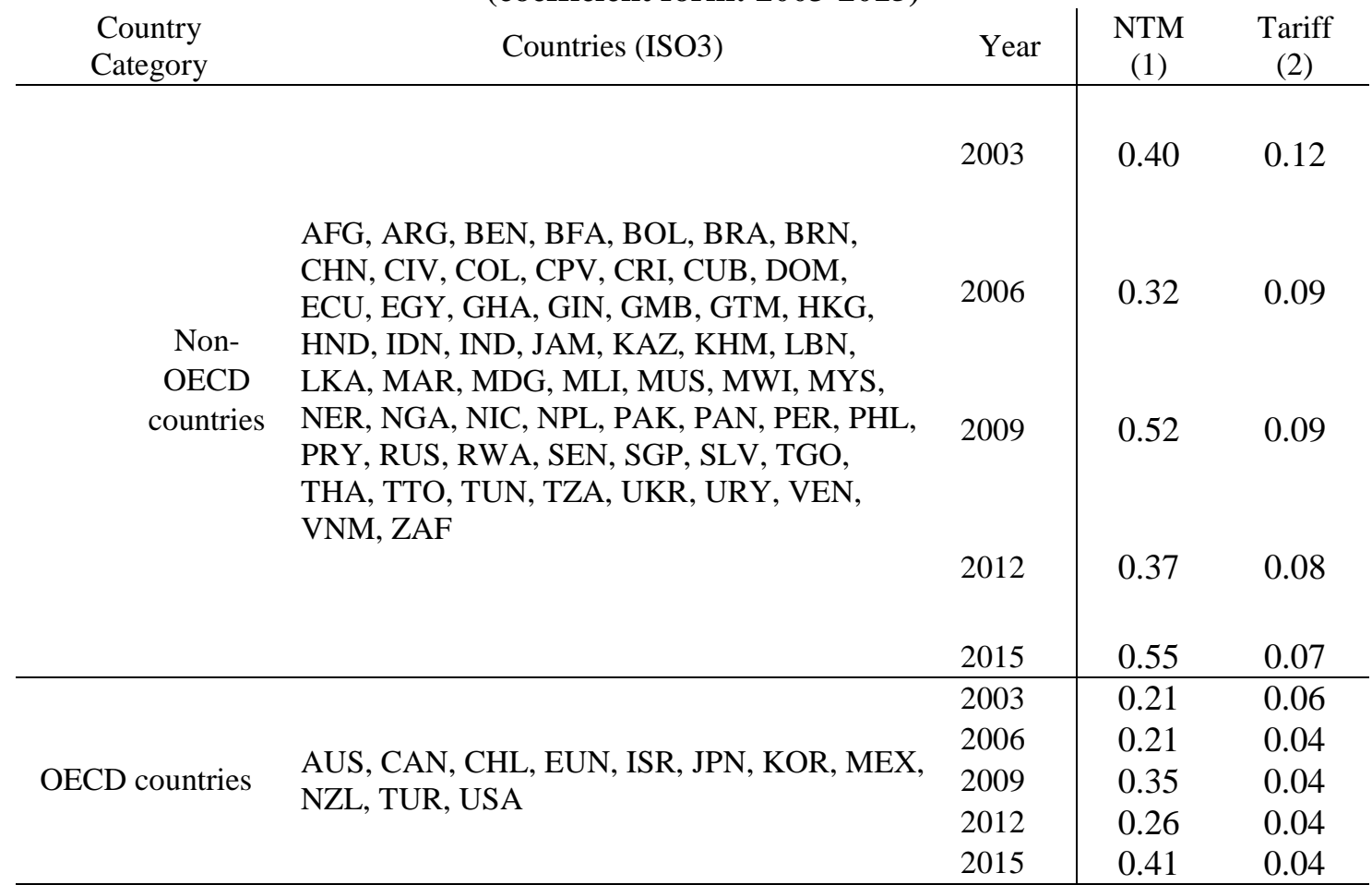

Note: The second column shows "ISO3" codes for countries in each category.

Table 2: Base Results: AVEs of NTMs Regressed on Lagged Tariffs (Levels and Changes)

\begin{tabular}{|c|c|c|c|c|c|c|}
\hline \multirow{2}{*}{ Independent variable } & \multicolumn{3}{|c|}{ Dependent variable: $\ln \left(1+N T M_{t}\right)$} & \multicolumn{3}{|c|}{ Dependent variable: $\ln \left(1+\Delta N T M_{t}\right)$} \\
\hline & (1) & (2) & (3) & (4) & $(5)$ & $(6)$ \\
\hline $\ln \left(1+\operatorname{tariff}_{\mathrm{t}-1}\right)$ & $\begin{array}{r}0.17 * * * \\
(0.00)\end{array}$ & $\begin{array}{l}-0.22 * * * \\
(0.01)\end{array}$ & $\begin{array}{l}-0.07 * * * \\
(0.01)\end{array}$ & & & \\
\hline $\ln \left(1+\Delta \operatorname{tariff}_{\mathrm{t}-1}\right)$ & & & & $\begin{array}{c}-0.05 * * * \\
(0.01)\end{array}$ & $\begin{array}{c}-0.05 * * * \\
(0.01)\end{array}$ & $\begin{array}{l}-0.02 * * \\
(0.01)\end{array}$ \\
\hline Constant & $\begin{array}{l}0.24 * * * \\
(0.00)\end{array}$ & $\begin{array}{l}0.27 * * * \\
(0.00)\end{array}$ & $\begin{array}{l}0.25 * * * \\
(0.00)\end{array}$ & $\begin{array}{l}-0.02 * * * \\
(0.00)\end{array}$ & $\begin{array}{l}-0.02 * * * \\
(0.00)\end{array}$ & $\begin{array}{l}-0.02 * * * \\
(0.00)\end{array}$ \\
\hline Obse & 950,037 & 950,037 & 950,037 & 753,645 & 753,645 & 753,645 \\
\hline Product-Country Effects & NO & YES & YES & NO & YES & YES \\
\hline Time-specific Effects & NO & NO & YES & NO & NO & YES \\
\hline R-squared & 0.002 & 0.006 & 0.03 & 0.0001 & 0.0001 & 0.04 \\
\hline Wald Test p-value & 0.00 & 0.00 & 0.00 & 0.00 & 0.00 & 0.00 \\
\hline Country-product group & & 252,965 & 252,965 & & 227,900 & 227,900 \\
\hline
\end{tabular}


Note: Regressions in columns 1 and 4 are uses pooled OLS. Regressions in columns 2-3 and 5-6 are estimated using panel fixed effects approach, with product-country specific effects. Time dummies are included in regressions in columns 3 and 6 . Robust standard errors in parentheses. $* * * * *, *$ stand for significance at the $1 \%, 5 \%$, and $10 \%$ level.

Table 3: Results for OECD and non-OECD Countries (Levels and Changes)

\begin{tabular}{|c|c|c|c|c|}
\hline \multirow{3}{*}{ Independent variable } & \multicolumn{2}{|c|}{ Dependent variable: $\ln \left(1+N T M_{t}\right)$} & \multicolumn{2}{|c|}{ Dependent variable: $\ln \left(1+\Delta N T M_{t}\right)$} \\
\hline & OECD & Non-OECD & OECD & Non-OECD \\
\hline & (1) & $(2)$ & (3) & (4) \\
\hline $\ln \left(1+\operatorname{tariff} f_{\mathrm{t}-1}\right)$ & $\begin{array}{c}-0.12 * * * \\
(0.02)\end{array}$ & $\begin{array}{c}-0.06 * * * \\
(0.01)\end{array}$ & & \\
\hline $\ln \left(1+\Delta \operatorname{tariff}_{\mathrm{t}-1}\right)$ & & & $\begin{array}{l}-0.10^{*} \\
(0.02)\end{array}$ & $\begin{array}{l}-0.01 \\
(0.01)\end{array}$ \\
\hline Constant & $\begin{array}{c}0.16 * * * \\
(0.003)\end{array}$ & $\begin{array}{c}0.28 * * * \\
(0.001)\end{array}$ & $\begin{array}{c}-0.09 * * * \\
(0.005)\end{array}$ & $\begin{array}{c}-0.004 \\
(0.002)\end{array}$ \\
\hline Observations & 205,066 & 744,971 & 163,191 & 590,454 \\
\hline Product-Country Effects & YES & YES & YES & YES \\
\hline Time-specific Effects & YES & YES & YES & YES \\
\hline R-squared & 0.04 & 0.03 & 0.04 & 0.04 \\
\hline Country-product group & 51,171 & 201,787 & 49,559 & 178,341 \\
\hline
\end{tabular}

Note: The regressions are re-run for sub-samples by dividing economies into OECD and non-OECD for lagged tariff, levels and changes. Robust standard errors in parentheses. $* * *, * * *$ stand for significance at the $1 \%, 5 \%$, and $10 \%$ level.

Table 4: Results for Agricultural and Manufacturing Sectors and Economies (Levels and Changes)

\begin{tabular}{|c|c|c|c|c|}
\hline \multirow[b]{2}{*}{$\begin{array}{l}\text { PANEL A: } \\
\text { OECD countries }\end{array}$} & \multicolumn{2}{|c|}{$\begin{array}{l}\text { Dependent variable: } \ln (1+ \\
\left.N T M_{t}\right)\end{array}$} & \multicolumn{2}{|c|}{ Dependent variable: $\ln \left(1+\Delta N T M_{t}\right)$} \\
\hline & $\begin{array}{l}\text { Agricultural } \\
\text { sector } \\
\text { (1) }\end{array}$ & $\begin{array}{l}\text { Manufacturing } \\
\text { sector } \\
\text { (2) }\end{array}$ & $\begin{array}{l}\text { Agricultural } \\
\text { sector } \\
\text { (3) }\end{array}$ & $\begin{array}{l}\text { Manufacturing } \\
\text { sector } \\
\text { (4) }\end{array}$ \\
\hline $\ln \left(1+\operatorname{tariff}_{\mathrm{t}-1}\right)$ & $\begin{array}{l}-0.02 \\
(0.03)\end{array}$ & $\begin{array}{c}-0.23 * * * \\
(0.02)\end{array}$ & & \\
\hline $\ln \left(1+\Delta \operatorname{tariff} f_{\mathrm{t}-1}\right)$ & & & $\begin{array}{c}-0.10 * * \\
(0.04)\end{array}$ & $\begin{array}{c}-0.09 * * * \\
(0.03)\end{array}$ \\
\hline Constant & $\begin{array}{c}0.19^{* * * *} \\
(0.01)\end{array}$ & $\begin{array}{c}0.16^{* * * *} \\
(0.00)\end{array}$ & $\begin{array}{c}-0.18 * * * \\
(0.02)\end{array}$ & $\begin{array}{c}-0.08 * * * \\
(0.00)\end{array}$ \\
\hline Observations & 24,932 & 180,134 & 18,237 & 144,954 \\
\hline Product-Country Effects & YES & YES & YES & YES \\
\hline Time-specific Effects & YES & YES & YES & YES \\
\hline $\mathrm{R}$-squared & 0.04 & 0.04 & 0.05 & 0.03 \\
\hline Country-product group & 6,618 & 44,560 & 6,302 & 43,257 \\
\hline \multirow{2}{*}{$\begin{array}{c}\text { PANEL B: } \\
\text { Non-OECD countries }\end{array}$} & \multicolumn{2}{|c|}{$\begin{array}{c}\text { Dependent variable: } \ln (1+ \\
N_{T}(1)\end{array}$} & \multicolumn{2}{|c|}{ Dependent variable: $\ln \left(1+\Delta N T M_{t}\right)$} \\
\hline & $\begin{array}{l}\text { Agricultural } \\
\text { sector } \\
\text { (5) }\end{array}$ & $\begin{array}{l}\text { Manufacturing } \\
\text { sector } \\
\text { (6) }\end{array}$ & $\begin{array}{l}\text { Agricultural } \\
\text { sector } \\
\text { (7) }\end{array}$ & $\begin{array}{c}\text { Manufacturing } \\
\text { sector } \\
\text { (8) }\end{array}$ \\
\hline $\ln \left(1+\operatorname{tarif} f_{\mathrm{t}-1}\right)$ & $\begin{array}{l}0.05^{* *} \\
(0.02)\end{array}$ & $\begin{array}{c}-0.09 * * * \\
(0.01)\end{array}$ & & \\
\hline $\ln \left(1+\Delta\right.$ tarif $\left.f_{\mathrm{t}-1}\right)$ & & & $\begin{array}{l}-0.05 \\
(0.03)\end{array}$ & $\begin{array}{l}-0.01 \\
(0.01)\end{array}$ \\
\hline Constant & $\begin{array}{c}0.39 * * * \\
(0.00)\end{array}$ & $\begin{array}{c}0.26^{* * * *} \\
(0.00)\end{array}$ & $\begin{array}{l}-0.01 \\
(0.01) \\
\end{array}$ & $\begin{array}{l}-0.00 \\
(0.00)\end{array}$ \\
\hline Observations & 79,983 & 664,988 & 57,402 & 533,052 \\
\hline Product-Country Effects & YES & YES & YES & YES \\
\hline Time-specific Effects & YES & YES & YES & YES \\
\hline R-squared & 0.07 & 0.04 & 0.07 & 0.04 \\
\hline Country-product group & 23,565 & 178,222 & 19,743 & 158,598 \\
\hline
\end{tabular}


Note: The regressions are for sub-samples splitting economies into OECD and non-OECD and sectors into sectors with agricultural sectors and manufactured sectors. Robust standard errors in parentheses. $* * *, * * *$ stand for significance at the $1 \%$, $5 \%$, and $10 \%$ level.

Table 5: AVEs of NTMs Regressed on Lagged Tariffs for Different Sectors and Economies (Levels and Changes)

\begin{tabular}{|c|c|c|c|c|}
\hline \multirow[b]{2}{*}{$\begin{array}{l}\text { PANEL A: } \\
\text { OECD countries }\end{array}$} & \multicolumn{2}{|c|}{ Dependent variable: $\ln \left(1+N T M_{t}\right)$} & \multicolumn{2}{|c|}{ Dependent variable: $\ln \left(1+\Delta N T M_{t}\right)$} \\
\hline & $\begin{array}{l}\text { Above average } \\
\text { UR cut } \\
\text { (1) }\end{array}$ & $\begin{array}{l}\text { Below average } \\
\text { UR cut } \\
\text { (2) }\end{array}$ & $\begin{array}{l}\text { Above average } \\
\text { UR cut } \\
\text { (3) }\end{array}$ & $\begin{array}{c}\text { Below average } \\
\text { UR cut } \\
\text { (4) }\end{array}$ \\
\hline $\ln \left(1+\right.$ tarif $\left.f_{\mathrm{t}-1}\right)$ & $\begin{array}{c}-0.28 * * * \\
(0.03)\end{array}$ & $\begin{array}{c}-0.07 * * * \\
(0.02)\end{array}$ & & \\
\hline $\ln \left(1+\Delta\right.$ tariff $\left._{\mathrm{t}-1}\right)$ & & & $\begin{array}{l}-0.28 \\
(0.06)\end{array}$ & $\begin{array}{l}-0.04 \\
(0.03)\end{array}$ \\
\hline Constant & $\begin{array}{c}0.16 * * * \\
(0.00)\end{array}$ & $\begin{array}{c}0.16^{* * * *} \\
(0.00)\end{array}$ & $\begin{array}{c}-0.07 * * * \\
(0.01)\end{array}$ & $\begin{array}{c}-0.13 * * * \\
(0.01)\end{array}$ \\
\hline $\begin{array}{l}\text { Observations } \\
\text { Product-Country Effects } \\
\text { Time-specific Effects } \\
\text { R-squared } \\
\text { Country-product group } \\
\end{array}$ & $\begin{array}{l}132,407 \\
\text { YES } \\
\text { YES } \\
0.05 \\
32,514 \\
\end{array}$ & $\begin{array}{c}72,659 \\
\text { YES } \\
\text { YES } \\
0.02 \\
18,664 \\
\end{array}$ & $\begin{array}{l}106,794 \\
\text { YES } \\
\text { YES } \\
0.04 \\
31,639 \\
\end{array}$ & $\begin{array}{c}56,397 \\
\text { YES } \\
\text { YES } \\
0.02 \\
17,920 \\
\end{array}$ \\
\hline \multirow[b]{2}{*}{$\begin{array}{c}\text { PANEL B: } \\
\text { Non-OECD countries }\end{array}$} & \multicolumn{2}{|c|}{ Dependent variable: $\ln \left(1+N T M_{t}\right)$} & \multicolumn{2}{|c|}{ Dependent variable: $\ln \left(1+\Delta N T M_{t}\right)$} \\
\hline & $\begin{array}{c}\text { Above average } \\
\text { UR cut } \\
(5)\end{array}$ & $\begin{array}{c}\text { Below average } \\
\text { UR cut } \\
(6)\end{array}$ & $\begin{array}{c}\text { Above average } \\
\text { UR cut } \\
(7) \\
\end{array}$ & $\begin{array}{c}\text { Below average } \\
\text { UR cut } \\
(8) \\
\end{array}$ \\
\hline $\ln \left(1+\right.$ tarif $\left.f_{\mathrm{t}-1}\right)$ & $\begin{array}{c}-0.16^{* * * *} \\
(0.01)\end{array}$ & $\begin{array}{c}0.01 \\
(0.01)\end{array}$ & & \\
\hline $\ln \left(1+\Delta\right.$ tariff $\left._{\mathrm{t}-1}\right)$ & & & $\begin{array}{l}-0.01 \\
(0.01)\end{array}$ & $\begin{array}{c}-0.03 * * \\
(0.01)\end{array}$ \\
\hline Constant & $\begin{array}{c}0.29 * * * \\
(0.00)\end{array}$ & $\begin{array}{c}0.27 * * * \\
(0.00)\end{array}$ & $\begin{array}{c}0.01 * * * \\
(0.00)\end{array}$ & $\begin{array}{c}-0.05 * * * \\
(0.00) \\
\end{array}$ \\
\hline Observations & 507,734 & 237,237 & 407,409 & 183,045 \\
\hline Product-Country Effects & YES & YES & YES & YES \\
\hline Time-specific Effects & YES & YES & YES & YES \\
\hline R-squared & 0.05 & 0.01 & 0.06 & 0.02 \\
\hline Country-product group & 135,175 & 66,612 & 120,729 & 57,612 \\
\hline
\end{tabular}

Note: The regressions are for sub-samples splitting economies into OECD and non-OECD and sectors into sectors with above average tariff cuts based on the Uruguay Round and those with a below average tariff cut. Robust standard errors in parentheses. $* * *, * *, *$ stand for significance at the $1 \%, 5 \%$, and $10 \%$ level.

Table 6: GMM Estimates: AVE of NTMs Regressed on Lagged Tariffs

\begin{tabular}{l|c|c}
\hline \multirow{2}{*}{ Independent variable } & \multicolumn{2}{|c}{ Dependent variable: $\ln \left(1+N T M_{t}\right)$} \\
\cline { 2 - 3 } & Differenced GMM & System GMM \\
\hline $\ln \left(1+\right.$ tariff $\left._{\mathrm{t}-1}\right)$ & $-0.25 * * *$ & $-0.22 * * *$ \\
& $(0.01)$ & $(0.02)$ \\
Constant & - & $-6.97 * * *$ \\
& & $(0.32)$ \\
\hline Observations & 768,305 & 925,874 \\
Time-specific Effects & YES & YES \\
Country-product group & 226,192 & 248,485 \\
F-test p value & 0.00 & 0.00 \\
Sargen test $\mathrm{p}$ value & 0.00 & 0.00 \\
Hansen Test p value & 0.00 & 0.00 \\
AB Test for AR(1) p value & 0.00 & 0.00 \\
AB Test for AR(2) p value & 0.00 & 0.00 \\
\hline \hline
\end{tabular}

Note: Robust standard errors in parentheses. $* * *, * *, *$ stand for significance at the $1 \%, 5 \%$, and $10 \%$ level. Sargan test of exogeneity of instrument subsets. Hansen Test of overidentification. Lagged NTM not reported. 
Figure 1: Evolution of Sample Average Frequency Index of NTMs and Tariff (2003-2015)

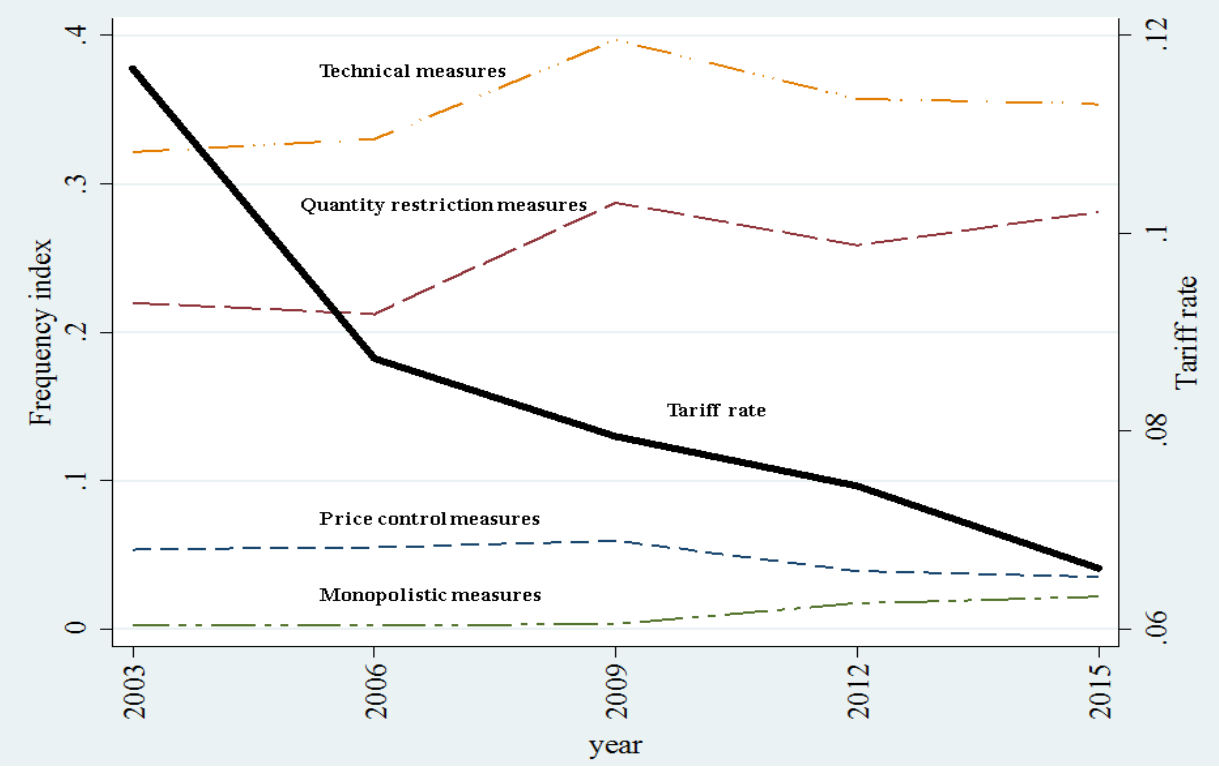

Note: Frequency index of NTMs and tariff is averaged across countries with available data for each year.

Figure 2: Evolution of Sample Average Tariffs and AVE of NTMs (2003-2015)

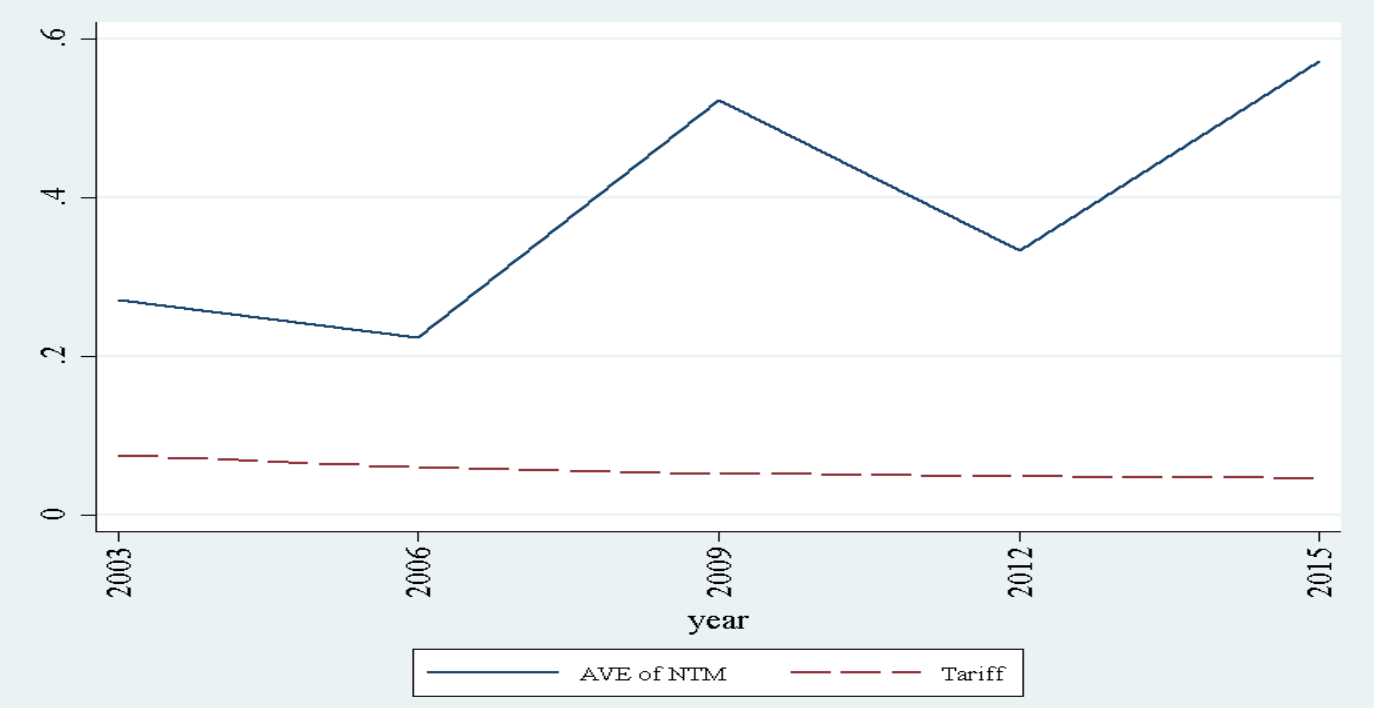

